\title{
Hydrogen sulfide modulates chromatin remodeling and inflammatory mediator production in response to endotoxin, but does not play a role in the development of endotoxin tolerance
}

Ester C. S. Rios ${ }^{1}$, Francisco G. Soriano ${ }^{1}$, Gabor Olah², Domokos Gerö², Bartosz Szczesny ${ }^{2}$ and Csaba Szabo ${ }^{*}$

\begin{abstract}
Background: Pretreatment with low doses of LPS (lipopolysaccharide, bacterial endotoxin) reduces the pro-inflammatory response to a subsequent higher LPS dose, a phenomenon known as endotoxin tolerance. Moreover, hydrogen sulfide $\left(\mathrm{H}_{2} \mathrm{~S}\right)$, an endogenous gaseous mediator (gasotransmitter) can exert anti-inflammatory effects. Here we investigated the potential role of $\mathrm{H}_{2} \mathrm{~S}$ in the development of LPS tolerance. THP1 differentiated macrophages were pretreated with the $\mathrm{H}_{2} \mathrm{~S}$ donor $\mathrm{NaHS}\left(1 \mathrm{mM}\right.$ ) or the $\mathrm{H}_{2} \mathrm{~S}$ biosynthesis inhibitor aminooxyacetic acid (AOAA, $1 \mathrm{mM}$ ).

Methods: To induce tolerance, cells were treated with a low concentration of LPS $(0.5 \mu \mathrm{g} / \mathrm{ml})$ for 4 or $24 \mathrm{~h}$, and then treated with a high concentration of LPS $(1 \mu \mathrm{g} / \mathrm{ml})$ for $4 \mathrm{~h}$ or $24 \mathrm{~h}$. In in vivo studies, male wild-type and $\mathrm{CSE}^{-1-}$ mice were randomized to the following groups: Control (vehicle); Endotoxemic saline for 3 days before the induction of endotoxemia with $10 \mathrm{mg} / \mathrm{kg}$ LPS) $\mathrm{mg} / \mathrm{kg}$; Tolerant (LPS at $1 \mathrm{mg} / \mathrm{kg}$ for 3 days, followed LPS at $10 \mathrm{mg} / \mathrm{kg}$ ). Animals were sacrificed after 4 or 12 h; plasma IL- 6 and TNF-a levels were measured. Changes in histone H3 and H4 acetylation were analyzed by Western blotting.

Results: LPS tolerance decreased pro-inflammatory cytokine production. AOAA did not affect the effect of tolerance on reducing cytokine production. Treatment of the cells with the $\mathrm{H}_{2} \mathrm{~S}$ donor reduced cytokine production. Induction of the tolerance increased the acetylation of $\mathrm{H} 3$; AOAA reduced histone acetylation. $\mathrm{H}_{2} \mathrm{~S}$ donation increased histone acetylation. Tolerance did not affect the responses to $\mathrm{H}_{2} \mathrm{~S}$ with respect to histone acetylation.

Conclusions: In conclusion, both LPS tolerance and $\mathrm{H}_{2} \mathrm{~S}$ donation decrease LPS-induced cytokine production in vitro and modulate histone acetylation. However, endogenous, CSE-derived $\mathrm{H}_{2} \mathrm{~S}$ does not appear to play a significant role in the development of LPS tolerance.
\end{abstract}

Keywords: Hydrogen sulfide, Endotoxin, Cytokines, Macrophages, Tolerance

\footnotetext{
* Correspondence: szabocsaba@aol.com

${ }^{2}$ Department of Anesthesiology, University of Texas Medical Branch, 601

Harborside Drive, Building 21, Room 4.202D, Galveston, TX 77555-1102, USA

Full list of author information is available at the end of the article
} 


\section{Background}

Sepsis, a systemic inflammation caused by pathogens, remains a significant clinical problem $[1,2]$. Amongst a multitude of pathophysiological events affecting the cardiovascular and immune system during sepsis, the outcome of sepsis is significantly affected by the severity of vascular disturbances, compromising oxygen delivery to the tissues, contributing to the development of multiple organ dysfunction. In the early phase of sepsis and septic shock there is an intense release of pro inflammatory mediators that can promote tissue injury and multiple organ dysfunction [3-7].

The induction of tolerance to lipopolysaccharide (LPS) has been investigated for several decades as a potential therapeutic approach for sepsis [8-18]. LPS tolerance downregulates the inflammatory response in septic shock while also increasing the ability of a host to eliminate the pathogens; it exerts protective effects in several models of sepsis and polymicrobial infection [14-18]. Inflammatory gene silencing resulting from tolerance can persist for days to weeks [8-10]. The mechanisms involved in LPS tolerance include toll-like receptor desensitization as well as the suppression of the inflammatory signaling pathways that regulate the production of anti-inflammatory cytokines, at least in part via epigenetic changes [11]. Chromatin remodeling during the period of LPS tolerance development modifies gene transcription profile and regulates or silences a host of genes in response to a subsequent challenge [12, 13]. LPS tolerance also modulates the production of reactive oxygen and nitrogen species (ROS/RNS) [16].

Hydrogen sulfide $\left(\mathrm{H}_{2} \mathrm{~S}\right)$ emerges as a novel gaseous mediator and signaling molecule, with multiple roles in health and disease [19]. Among other pathways, $\mathrm{H}_{2} \mathrm{~S}$ regulates the activation of ERK and p38 MAP kinase, modulates cell proliferation and regulates oxidant-induced cell death [19-25]. Here we investigated effect of modulation of $\mathrm{H}_{2} \mathrm{~S}$ homeostasis (by $\mathrm{H}_{2} \mathrm{~S}$ donation or inhibition of endogenous $\mathrm{H}_{2} \mathrm{~S}$ generation) in in vitro/vivo models of LPS tolerance and endotoxemia.

\section{Methods}

\section{Macrophage culture and differentiation}

THP1 monocytes obtained from ATCC were differentiated into macrophage using $100 \mathrm{nM}$ phorbol myristate acetate (PMA) for 5 h in RPMI 1640 supplemented with $2 \mathrm{mM} \mathrm{L-}$ glutamine, $100 \mathrm{U} / \mathrm{ml}$ penicillin, $100 \mu \mathrm{g} / \mathrm{ml}$ streptomycin and $10 \%$ fetal bovine serum (FBS) (Sigma). Ultrapure Escherichia coli 0111:B4 LPS free of lipoproteins was obtained from Invitrogen (San Diego, CA).

\section{In vitro model of tolerance and sepsis}

THP1 cells were plated in $22 \mathrm{~mm}$ tissue culture dishes $\left(2 \times 10^{6}\right.$ cells/dish). In the first experimental design, four groups of cells were studied (Fig. 1a). Group "C" (i.e. "Control") was designated as the control group that was maintained with medium and received vehicle only. Group "T" (i.e. "Tolerance") received a single and low concentration of LPS at $0.5 \mu \mathrm{g} / \mathrm{ml}$ for $4 \mathrm{~h}$, followed by washout, and further incubation for $4 \mathrm{~h}$. Group "TD” (i.e. "Tolerance + Direct Challenge") received the same low concentration of LPS $(0.5 \mu \mathrm{g} / \mathrm{ml})$ as the "T" group, followed, at $4 \mathrm{~h}$, by a higher concentration of LPS $(1 \mu \mathrm{g} / \mathrm{ml})$ for an additional 4-h period. Group "D” (i.e. "Direct Challenge") did not receive the low concentration of LPS; instead it received vehicle at the beginning of the experiment, but it received the higher concentration of LPS $(1 \mu \mathrm{g} / \mathrm{ml}) 4 \mathrm{~h}$ later. Culture supernatant was collected $4 \mathrm{~h}$ after the challenge with the higher concentration of LPS $(1 \mu \mathrm{g} /$ $\mathrm{ml}$, i.e. $8 \mathrm{~h}$ after the start of the experiment). In the next set of experimental design (Fig. 1b), a similar approach was used, but the time period for both the first, tolerizing concentration $(0.5 \mu \mathrm{g} / \mathrm{ml})$ and for the second, higher ("challenge") concentration $(1 \mu \mathrm{g} / \mathrm{ml})$ was extended to $24 \mathrm{~h}$. In these experiments, culture supernatant was collected $24 \mathrm{~h}$ after the challenge with the higher concentration of LPS $(1 \mu \mathrm{g} / \mathrm{ml}$, i.e. $48 \mathrm{~h}$ after the start of the experiment). Cell viability was not effected under these experimental conditions (Fig. 2).

To study the effect of the $\mathrm{H}_{2} \mathrm{~S}$ biosynthesis inhibitor aminooxyacetic acid (AOAA) or the $\mathrm{H}_{2} \mathrm{~S}$ donor NaHS, the experimental design shown in Fig. $3 a$ and $b$ was employed. The Control group (Group "C") received 2 sets of treatment (each times $30 \mathrm{~min}$ ) with the $\mathrm{H}_{2} \mathrm{~S}$ modulators (each time, the $30 \mathrm{~min}$ exposure was followed by wash-outs, prior to the subsequent application of LPS). Since our goal was to understand the effect of $\mathrm{H}_{2} \mathrm{~S}$ modulators on the development of LPS tolerance, the groups that received the low (tolerizing) exposure to LPS (Groups "T" and "TD") received $30 \mathrm{~min}$ of treatment with either NaHS or AOAA before the low concentration of LPS. On the other hand, for the group designated to serve as the "Direct Challenge" group ("DC") by exposing it to the higher concentration of LPS (group "D") the exposure to NaHS or AOAA was applied 30 min prior to this very stimulus. This experimental design was employed both in the shorter experimental design $(4 \mathrm{~h}$ of low concentration of LPS exposure, followed by $4 \mathrm{~h}$ of high concentration of LPS exposure, followed by the collection of culture supernatant at $8 \mathrm{~h}$ ) (Fig. 3a) and in the longer experimental design (24 h of low concentration of LPS exposure, followed by $24 \mathrm{~h}$ of high concentration of LPS exposure, followed by the collection of culture supernatant at $48 \mathrm{~h}$ ) (Fig. 3b).

\section{In vivo model of tolerance and endotoxemia}

All procedures were performed in accordance to the Guide for the Care and Use of Laboratory Animals 


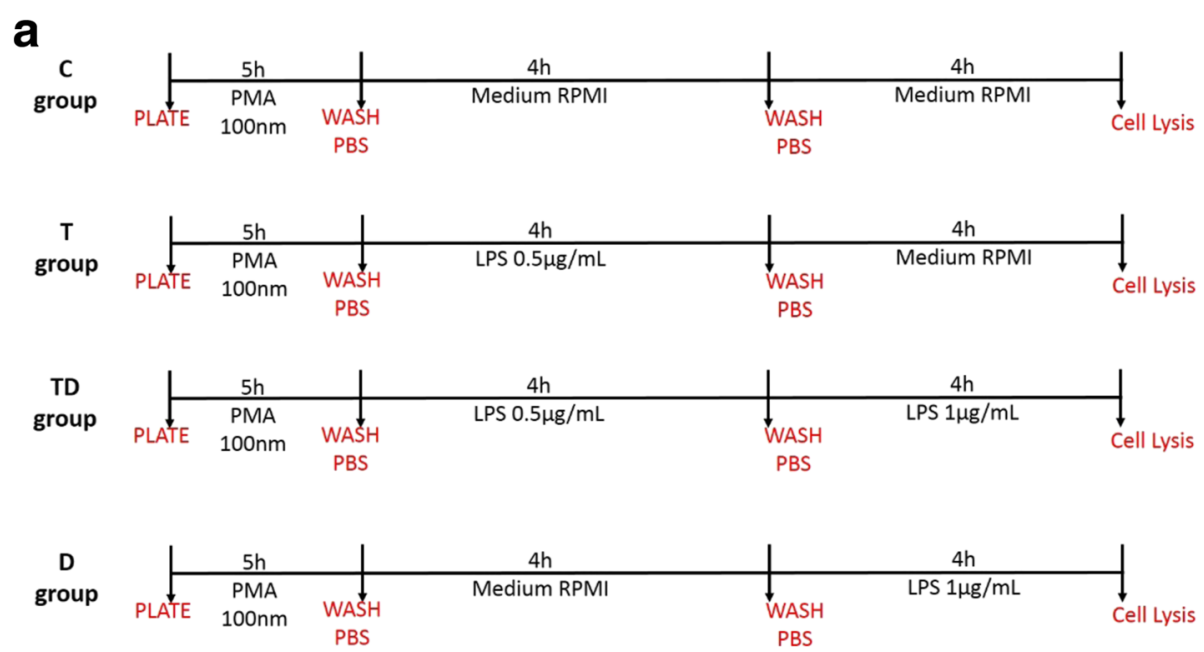

b
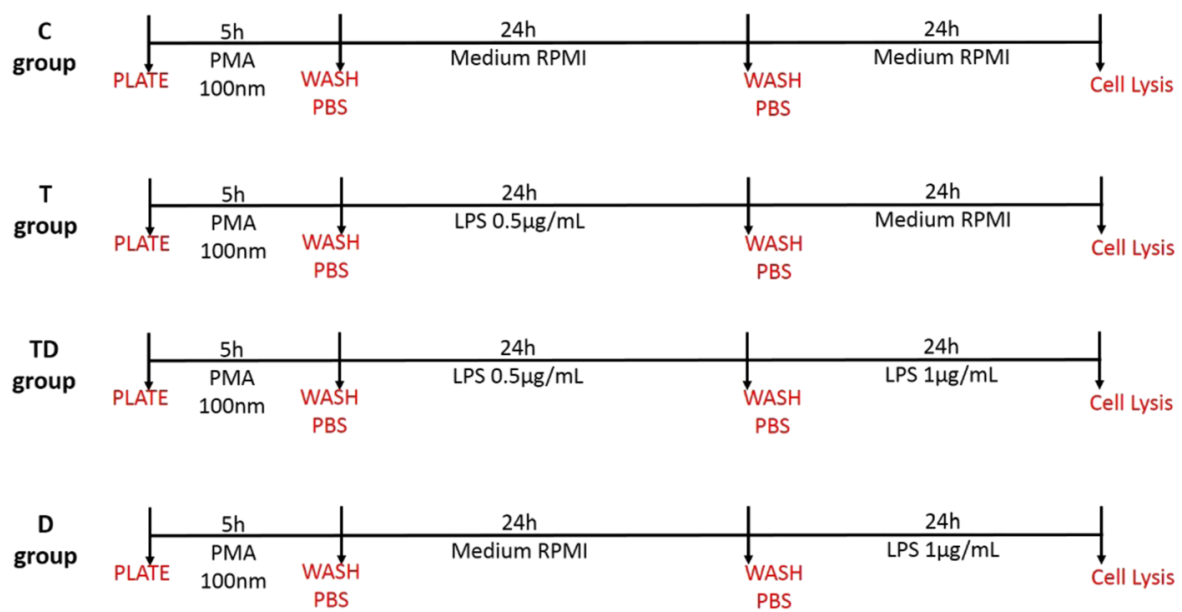

Fig. 1 In vitro experimental protocols of LPS tolerance used in the current study

published by the US National Institutes of Health and were was approved by UTMB's IACUC. Animals were anesthetized (i.p) with a mixture of ketamine $(80 \mathrm{mg} / \mathrm{kg})$ and xylazine $(10 \mathrm{mg} / \mathrm{kg})$. Male C57bl/6 wild-type mice or cystathionine $\gamma$-lyase (CSE)-deficient mice (a kind gift of Dr. Solomon Snyder, Johns Hopkins University, Baltimore, MD) were randomized in the following groups: Group C (control group) - no treatment; Group $\mathrm{D}$ (directly challenged/endotoxemic) - received $0.1 \mathrm{ml}$ normal saline i.p. during 3 days before the induction of endotoxemia (LPS $10 \mathrm{mg} / \mathrm{kg}$ ); Group TD (tolerant + endotoxemic) - animals received LPS $1 \mathrm{mg} / \mathrm{kg}$ i.p. during first 3 days before the induction of endotoxemia (LPS $10 \mathrm{mg} / \mathrm{kg}$ ). $2 \mathrm{ml}$ lactated Ringer's solution alone i.p. was administered immediately after endotoxemia induction. 4 or $12 \mathrm{~h}$ after endotoxemia induction, animals were sacrificed and plasma collected.

\section{Cell viability}

To estimate cell viability of the in vitro model of tolerance described before 3-(4,5-dimethyl-2-thiazolyl)- 2,5-diphenyl-2H-tetrazolium bromide (MTT) was added to the cells at a final concentration of $0.5 \mathrm{mg} / \mathrm{ml}$ and cultured at $37^{\circ} \mathrm{C}$ for $1 \mathrm{~h}$. Cells were washed with PBS and the formazan dye was dissolved in isopropanol. The amount of converted formazan dye was measured at $570 \mathrm{~nm}$ with a background measurement at $690 \mathrm{~nm}$ on spectrophotometer (Tecan Genius, Salzburg, Austria). Viable cell count was calculated as a percent of control cells.

\section{Western blot analysis}

THP-1 cells lysed in RIPA buffer and sonicated (3 times of $10 \mathrm{~s}$ ). The supernatants were preserved and protein concentration was determined by BCA (BioRad). $25 \mu \mathrm{g}$ cell extract was resuspended in equal volume of loading 


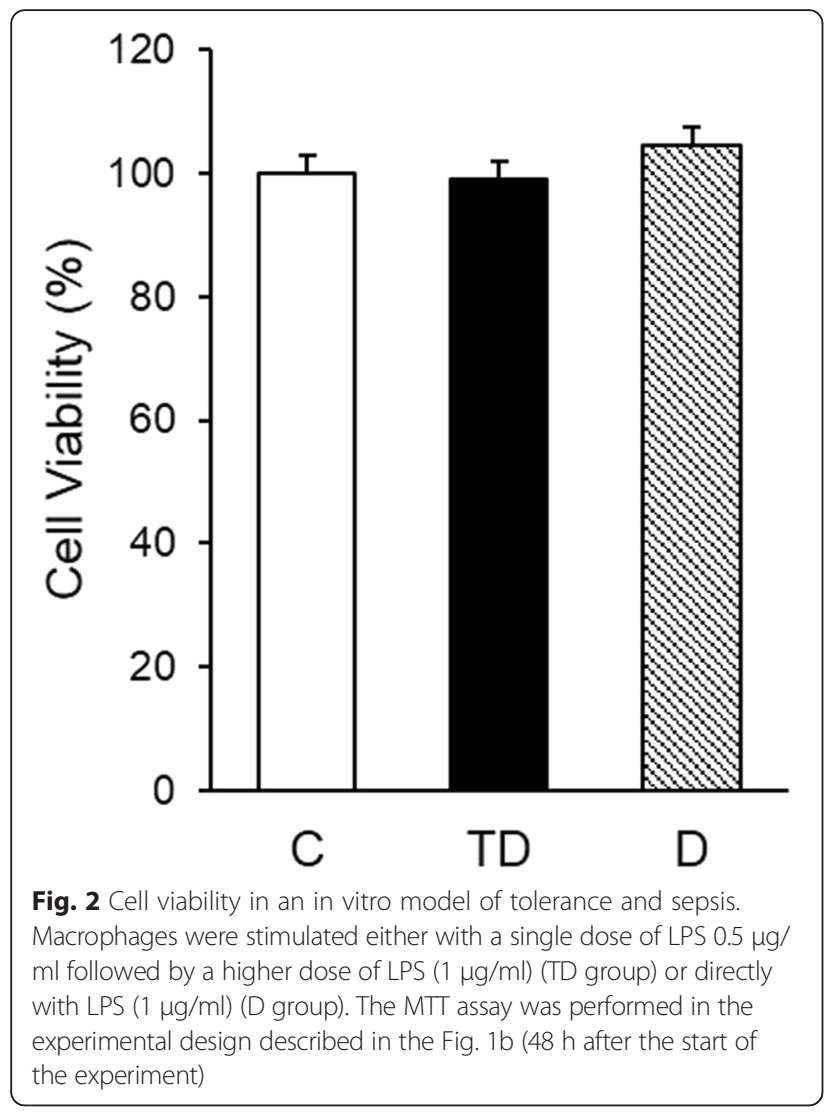

buffer (20 mM Tris-HCl, pH 6.8; 2 \% SDS; 10 \% glycerol; $6 \mathrm{M}$ Urea $2 \%$; $15 \%$-mercaptoethanol; urea 6 and $0.01 \%$ bromophenol blue), boiled for 2 min and electrophoresed on 8-12 \% SDS-polyacrylamide gels. After electrophoretic separation, proteins were transferred to PDF membranes. Membranes were blocked with T20 Starting Buffer (Thermo Scientific) for $1 \mathrm{~h}$. Following primary antibodies at the dilution 1:1,000 were used: rabbit acetylated histone $\mathrm{H} 3$ at $\mathrm{N}$-terminal tail (Millipore 06-599), anti-histone $\mathrm{H} 4$ acetylated at lysine 5/8/12/16 (Millipore 06-866), HRP conjugated $\beta$-actin (Santa Cruz Biotechnology). The primary antibodies were incubated overnight at $4{ }^{\circ} \mathrm{C}$ the membranes were washed twice in TBST. A secondary horseradish-peroxidase-conjugated antibody (goat anti-rabbit, Cell Signaling) was then applied at a dilution of 1:5000 for $1 \mathrm{~h}$. Over a 30-min period, the blots were washed twice in TBST. Signal was obtained using Super Signal Detection Kit (Pierce, Rockford, IL, USA). Band intensity was quantified using Genetools (Syngene, Synoptics Ltd., USA) and normalized to $\beta$-actin.

\section{Measurement of cytokine production by THP-1 cells}

Cell culture medium and plasma samples were collected to measure TNF- $\alpha$ and IL- 6 by ELISA according to manufacturer's instructions (R\&D Technologies, USA).

\section{Statistical analysis}

All values were expressed as mean \pm standard error of the mean (SEM) from 5 or 6 repetitions per group for the cell culture and animal studies. Statistical analyses were performed using GraphPad InStat Software. Comparisons among experimental groups were performed by analysis of variance ONE-WAY ANOVA and Tukey's test was used as post hoc test to compare individual groups. A p-value less than 0.05 were considered significant.

\section{Results}

\section{$\mathrm{H}_{2} \mathrm{~S}$ modulates the production of IL- 6 and TNF- $a$ in a} THP-1 model of LPS tolerance

We first investigated the amount of IL- 6 and TNF- $\alpha$ released into the medium of cultured THP-1 cells treated with various combination of LPS (Figs. 4 and 5). Cells exposed initially to low concentration of LPS followed by high concentration of LPS (Tolerance and Direct Challenge: Group TD) produced significant less IL-6 (Fig. 4b) and TNF- $\alpha$ (Fig. 5b) than the amount of the cytokines produced in the Direct Challenge Group (Group D), validating the development of tolerance in our experimental protocol. Similarly, a pattern of tolerance was noted for TNF- $\alpha$ production in the shorter exposure protocol (shown in Fig. 1a) involving exposure to $4 \mathrm{~h}$ of the lower concentration of LPS, followed by $4 \mathrm{~h}$ of the higher concentration of LPS (Fig. 5a). Surprisingly, at the same time, in this shorter tolerization/exposure protocol, when evaluating IL-6 production, a pattern of additive cytokine production was seen: the amount of cytokines produced in the TD group was higher than the cytokines produced either by the $\mathrm{T}$ group or the $\mathrm{D}$ group (Fig. 4a).

Next, we investigated effect of inhibition of endogenous $\mathrm{H}_{2} \mathrm{~S}$ generation (using AOAA) or the effect $\mathrm{H}_{2} \mathrm{~S}$ donation (using $\mathrm{NaHS}$ ) on the responses characterized in the prior section. For $\mathrm{H}_{2} \mathrm{~S}$ biosynthesis inhibition AOAA was selected, because it is an inhibitor of two major $\mathrm{H}_{2} \mathrm{~S}$ generating enzymes: cystathionine- $\beta$-synthase (CBS) and cystathionine- $\gamma$-lyase (CSE) [26]. We did not observe any significant effect of AOAA on the production of IL6 and TNF- $\alpha$, either in the $4+4$ and $24+24$ h protocols (Figs. 4 and 5). However, pretreatment of the cells with NaHS significantly reduced the effect of LPS in all experimental groups (Figs. 4 and 5). The most pronounced effect of NaHS was noted on the production of IL- 6 and TNF- $\alpha$ at $24 \mathrm{~h}$ in Group "T" (Figs. 4b and 5b) suggesting that the inhibitory effect of $\mathrm{H}_{2} \mathrm{~S}$ on cytokine production is most pronounced when the longest time is given to exert its effect (in this case, cytokines were measured at $48 \mathrm{~h}$ relative to the exposure to NaHS and to $0.5 \mu \mathrm{g} / \mathrm{ml}$ LPS, as compared to the other groups, where the measurements of cytokines were conducted at $24 \mathrm{~h}$ after exposure to NaHS and LPS). One may also describe the 

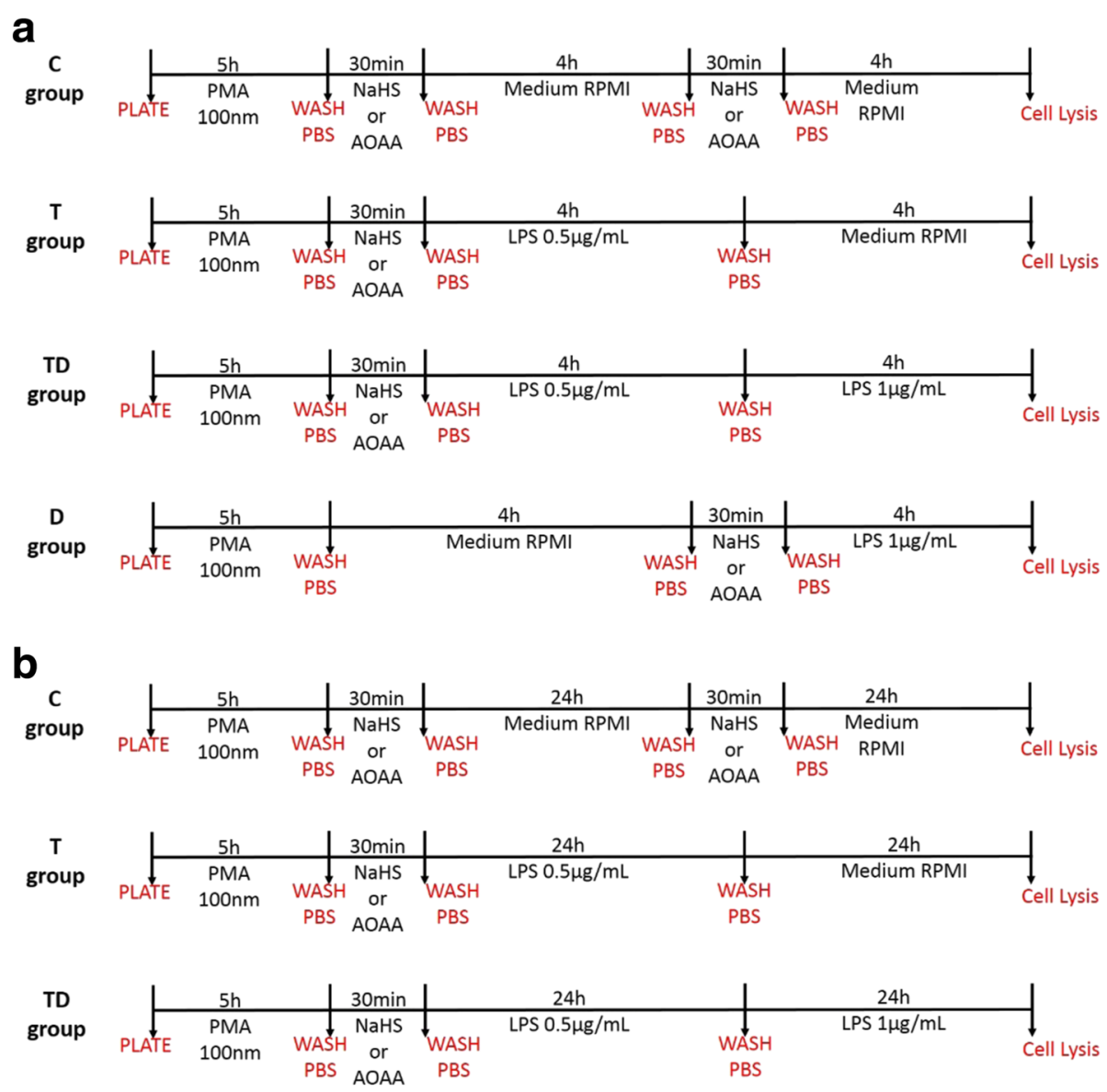

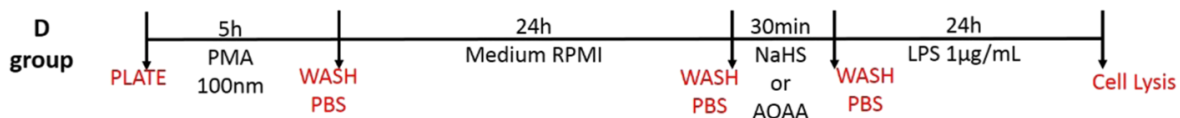

Fig. 3 Scheme showing the administration of AOAA and NaHS in the in vitro protocol. Part (a) depicts the shorter experimental design ( $4 \mathrm{~h}$ of low concentration of LPS exposure, followed by $4 \mathrm{~h}$ of high concentration of LPS exposure, followed by the collection of culture supernatant at $8 \mathrm{~h}$ ) and part (b) depicts the longer experimental design ( $24 \mathrm{~h}$ of low concentration of LPS exposure, followed by $24 \mathrm{~h}$ of high concentration of LPS exposure, followed by the collection of culture supernatant at $48 \mathrm{~h}$ )

observed effect of NaHS as follows: in the 48-h protocol it enhanced the tolerance-inducing effect of LPS on TNF- $\alpha$ and IL-6 production.

\section{$\mathrm{H}_{2} \mathrm{~S}$ modulates acetylation of histones 3 and 4 in a THP-1 model of LPS tolerance}

Chromatin remodeling is a hallmark of alterations in gene expression, and changes in histone acetylation constitute a key component of this response. We have recently demonstrated that $\mathrm{H}_{2} \mathrm{~S}$ can modulate gene expression and cytokine production through the modulation of chromatin remodeling in activated macrophages in vitro [27] Therefore, next, we tested whether the changes in expression of IL- 6 and TNF- $\alpha$ shown in Figs. 4 and 5 are associated with chromatin remodeling, and whether $\mathrm{H}_{2} \mathrm{~S}$ inhibition or $\mathrm{H}_{2} \mathrm{~S}$ donation modulates these responses in the context of LPS tolerance. We observed a reduced acetylation of both histones 3 and 4 in cells exposed to the higher concentration of LPS in the shorter $(4+4 \mathrm{~h})$ LPS tolerance protocol (Fig. 6a) and of $\mathrm{H} 4$ in the longer $(24+24 \mathrm{~h})$ protocol (Fig. $7 \mathrm{~b})$. AOAA, the inhibitor of endogenous $\mathrm{H}_{2} \mathrm{~S}$ production, reduced histone acetylation in the shorter-term $(4+4 \mathrm{~h})$ tolerance protocol in all four experimental groups, but did not affect histone acetylation in the longer-term $(24+24 \mathrm{~h})$ protocol. In contrast, treatment of the cells with the $\mathrm{H}_{2} \mathrm{~S}$ donor increased acetylation of $\mathrm{H} 3$ and $\mathrm{H} 4$, both in the shorter and the longer-term LPS tolerance protocols, with the effect being less pronounced in the "TD" group compared to the "T" or "D" groups (Figs. 6 and 7). In summary, histone acetylation was enhanced in the presence of $\mathrm{H}_{2} \mathrm{~S}$ donor, an effect, which partially correlated with the inhibitory effect of the $\mathrm{H}_{2} \mathrm{~S}$ donor on the production of IL-6 and TNF- $\alpha$ in the same experimental protocol. 


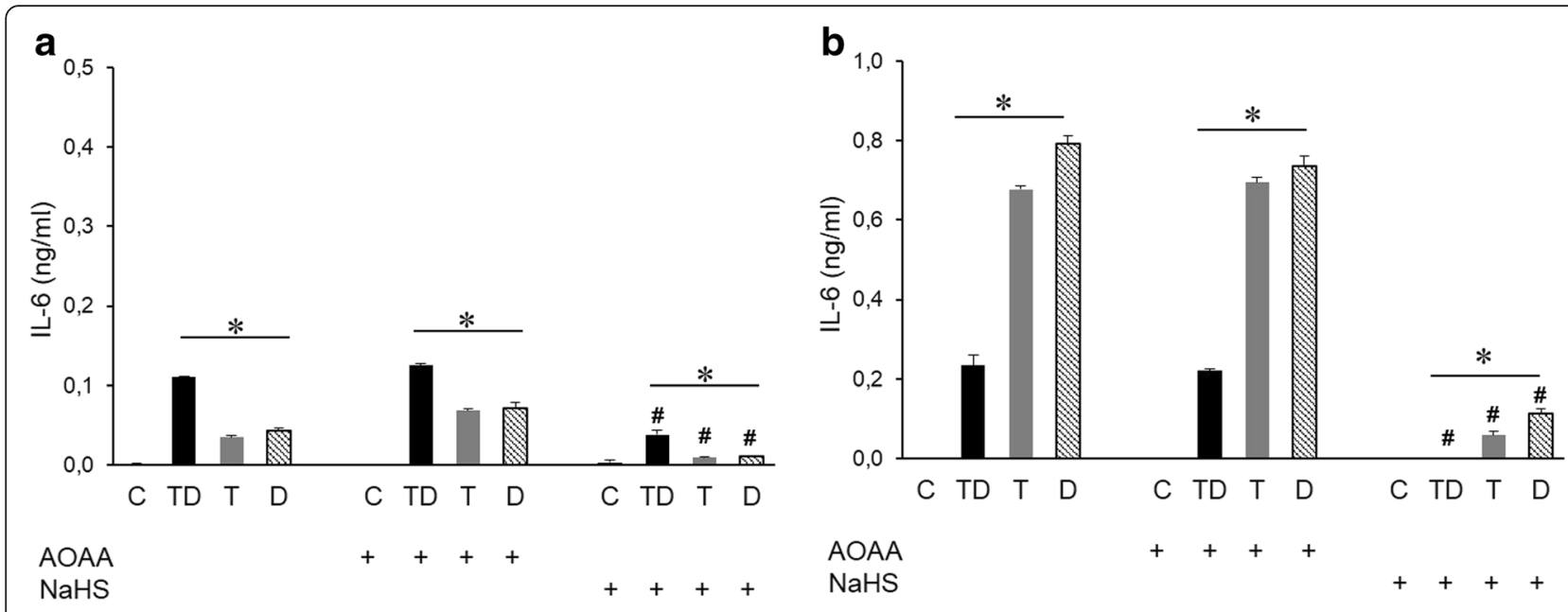

Fig. $4 \mathrm{H}_{2} \mathrm{~S}$ modulates the production of IL-6 in THP-1 cells treated with LPS. Macrophages were stimulated either with a single dose of LPS $0.5 \mu \mathrm{g} / \mathrm{ml}$ ( group), a single dose of LPS $0.5 \mu \mathrm{g} / \mathrm{ml}$ followed by a higher dose of LPS (1 $\mu \mathrm{g} / \mathrm{ml}$ ) (TD group) or directly with LPS (1 $\mu \mathrm{g} / \mathrm{ml})$ (D group). IL-6 concentration in the culture medium was measured after $4 \mathrm{~h}(\mathbf{a})$ or $24 \mathrm{~h}(\mathbf{b})$ after the final LPS treatment. The $\mathrm{H}_{2} \mathrm{~S}$ biosynthesis inhibitor $\mathrm{AOAA}$ and the $\mathrm{H}_{2} \mathrm{~S}$ donor were both applied at $1 \mathrm{mM}$. ${ }^{*} p<0.05$ TD vs. D groups; $\# p<0.05$ shows the inhibitory effect of $\mathrm{NaHS}$, compared to the respective group that did not receive the $\mathrm{H}_{2} \mathrm{~S}$ donor

\section{LPS-induced production of IL- 6 and TNF- $a$ is reduced in CSE-deficient mice during endotoxin tolerance}

Next, we compared the production of IL- 6 and TNF- $\alpha$ in a mouse model of LPS tolerance in wild-type (WT) and CSE knockout $\left(\mathrm{CSE}^{-/-}\right)$mice. To induce tolerance, animals were treated with a low dose $(0.5 \mathrm{mg} / \mathrm{kg} /$ day $)$ of LPS, followed by a single high dose $(10 \mathrm{mg} / \mathrm{kg})$ of LPS (animal group “TD”). Another group of animals was directly challenged with the high dose $(10 \mathrm{mg} / \mathrm{kg})$ of LPS (animal group "D") without any (tolerizing) pretreatment of a lower dose of LPS. Similar to the in vitro studies, we have used shorter-term and longer-term protocols; in one protocol the time of tolerizing and challenge was both $4 \mathrm{~h}$ and $4 \mathrm{~h}$ (Figs. 8a and 9a); in another protocol, the time of tolerizing, as well as the time of high-dose LPS challenge was both 12-12 $\mathrm{h}$ (Figs. 8b and 9b). In the shorter-term protocol, tolerance developed with respect to TNF- $\alpha$ production (Fig. 9a), but - similar to our findings with the shorter in vitro LPS tolerance protocol - it did develop not with respect to IL-6 production (Fig. 8a), while in the longer-term protocol, both mediators exhibited the

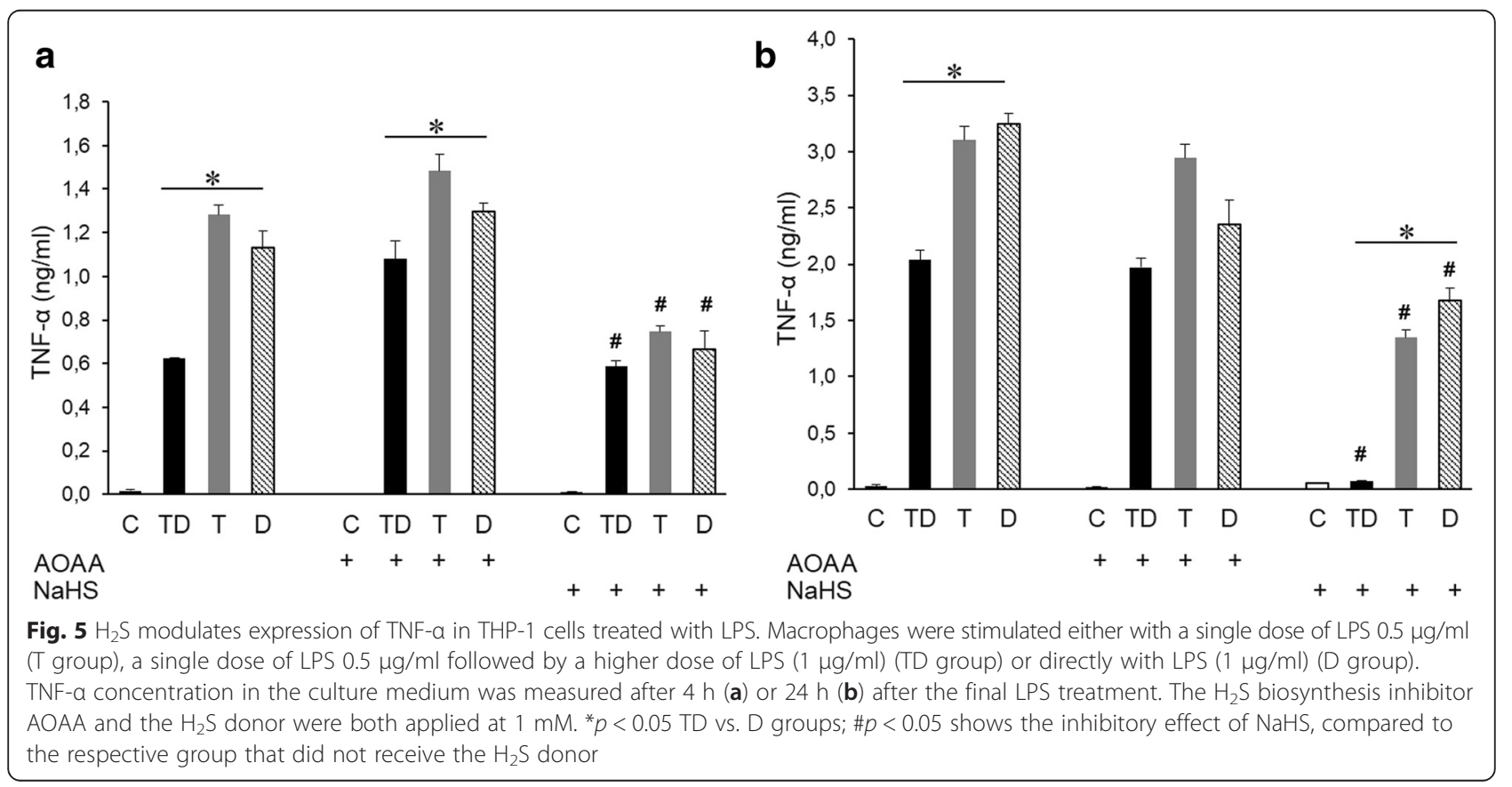



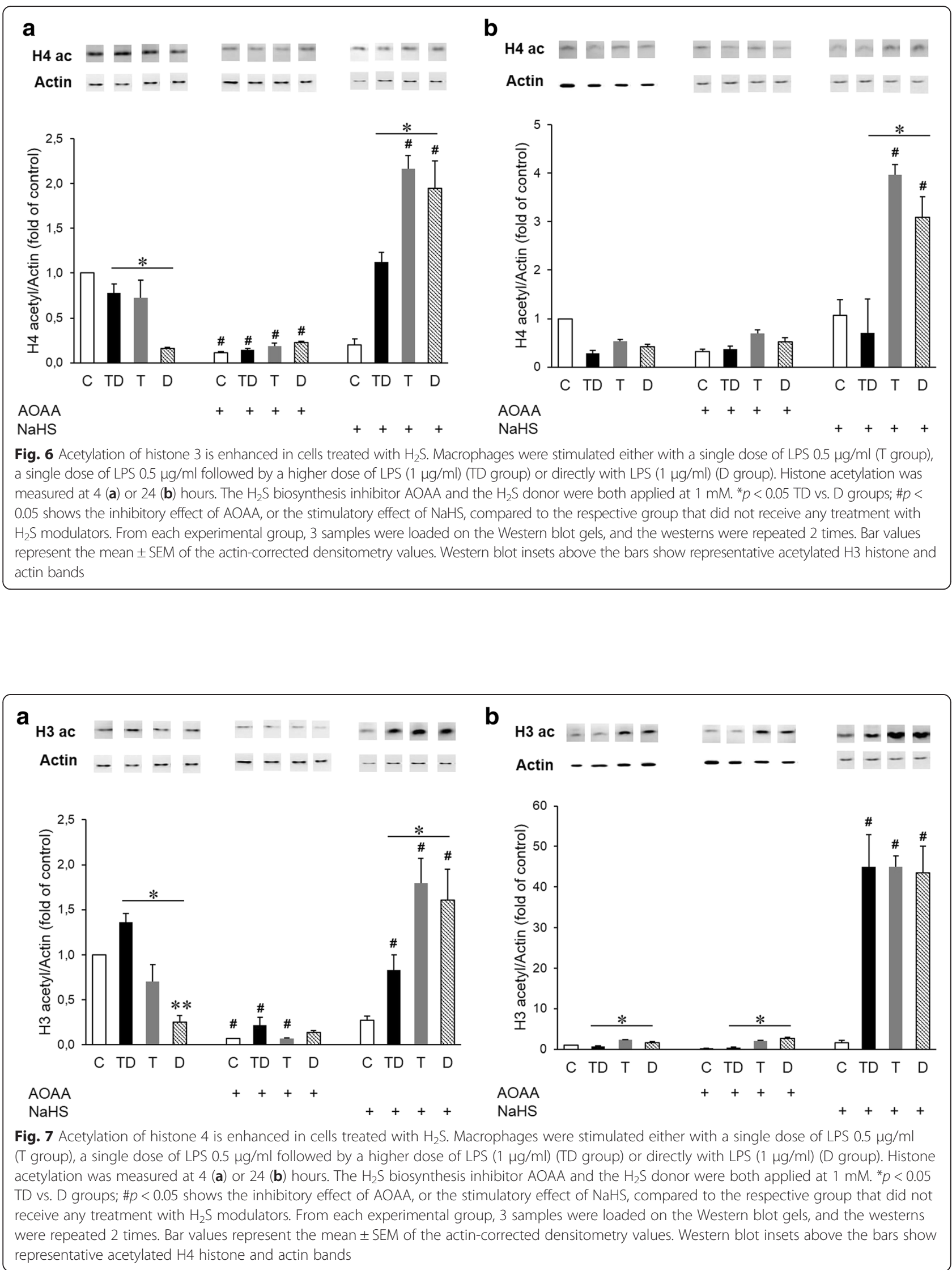

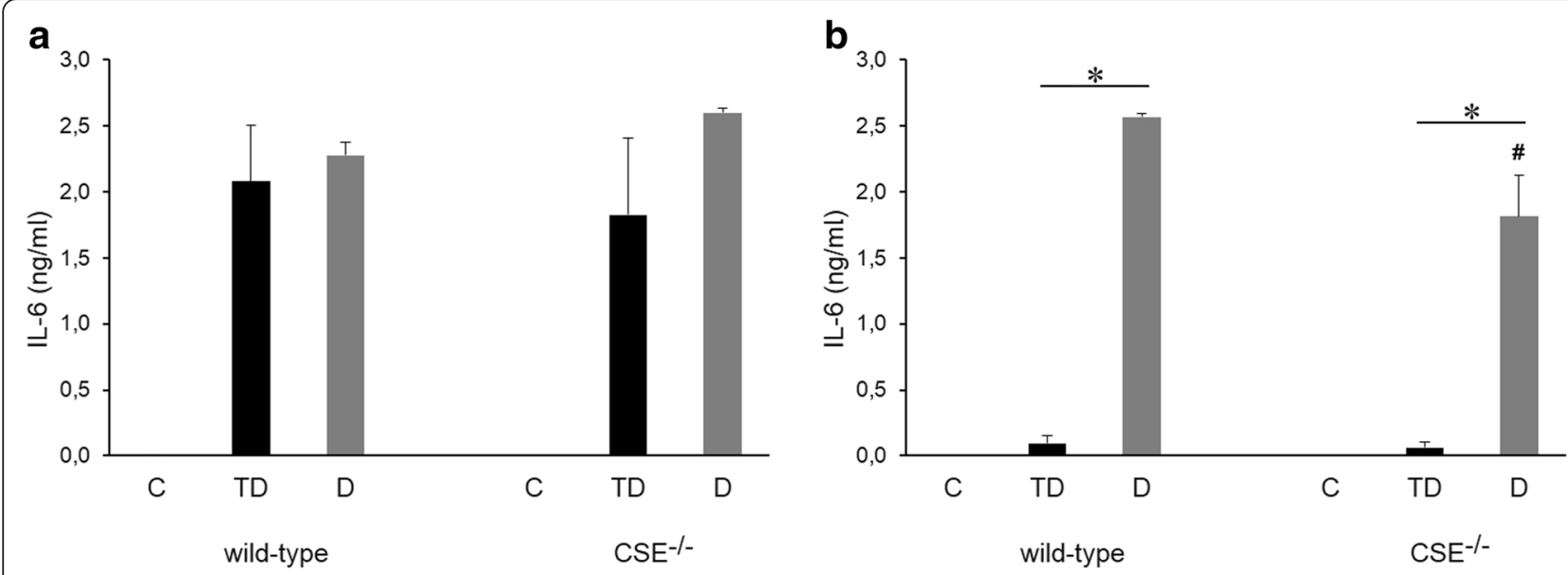

Fig. 8 Production of IL-6 in the plasma of LPS-treated wild-type and CSE ${ }^{-/}$mice during LPS tolerance. C57/J6 black wild type and $\mathrm{CSE}^{-/-}$mice were randomized into the following groups: C group: vehicle treatment; TD group: 1 mg/kg LPS during 3 days, followed by the induction of endotoxemia with $10 \mathrm{mg} / \mathrm{kg}$ LPS; D group: vehicle (instead of the tolerizing doses of LPS) before the challenge with $10 \mathrm{mg} / \mathrm{kg}$ LPS. Animals were euthanized at 4 (a) or 12 (b) hours after exposure to $10 \mathrm{mg} / \mathrm{kg}$ LPS. ${ }^{*} p<0.05$ TD vs. D groups; \#p $<0.05$ shows the inhibitory effect of CSE deficiency, compared to the respective wild-type group

expected tolerance phenomenon, i.e. the LPS-induced mediator production was significantly lower in the "TD" group when compared to the "D" group (Figs. 8b and 9b). CSE deficiency failed the affect the overall pattern of these responses; LPS tolerance continued to develop in the $\mathrm{CSE}^{-1-}$ mice; the main difference that we have observed between wild-type and $\mathrm{CSE}^{-1-}$ mice was that the LPS-induced cytokine responses were less pronounced in the "TD" group than in the "D" group in the longer-term protocol (Figs. $8 \mathrm{~b}$ and $9 \mathrm{~b}$ ) and, in the case of TNF- $\alpha$ production, both in the shorter-term and the longer-term protocols (Fig. 8a).

\section{Discussion}

Gene expression programs in response to microbes requires highly precise regulatory mechanisms in innate immune system cells. LPS tolerance is a well-known phenomenon that reduces cytokine release and inflammation, where the conditioning of the genes is dependent on modification of histones, and this is associated with selective reprogramming of several genes [8-11]. It has been shown that two categories of chromatin modifications induced by tolerance: one class associated with silencing of pro-inflammatory genes and a second class, associated with antimicrobial effectors [11].
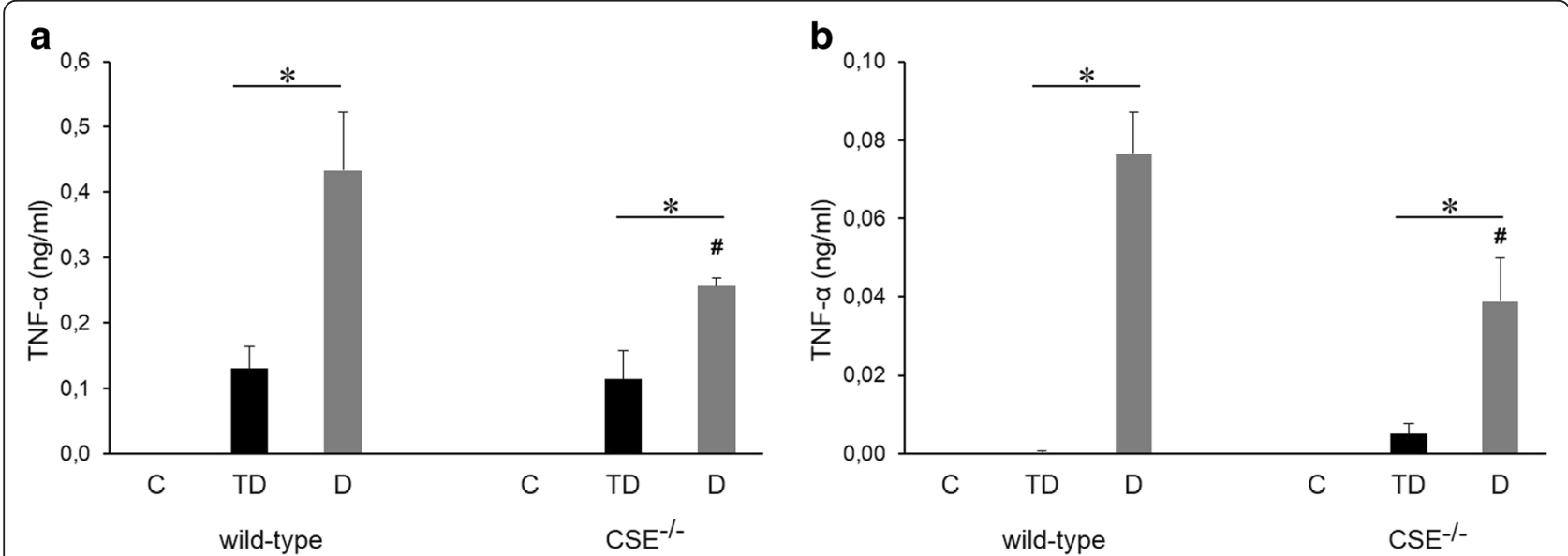

Fig. 9 Production of TNF-a in the plasma of LPS-treated wild-type and $\mathrm{CSE}^{-/-}$mice during LPS tolerance. C57/J6 black wild type and CSE ${ }^{-/-}$mice were randomized into the following groups: C group: vehicle treatment; TD group: $1 \mathrm{mg} / \mathrm{kg}$ LPS during 3 days, followed by the induction of endotoxemia with $10 \mathrm{mg} / \mathrm{kg}$ LPS; D group: vehicle (instead of the tolerizing doses of LPS) before the challenge with $10 \mathrm{mg} / \mathrm{kg}$ LPS. Animals were euthanized at 4 (a) or 12 (b) hours after exposure to $10 \mathrm{mg} / \mathrm{kg}$ LPS. ${ }^{*} p<0.05$ TD vs. D groups; $\# p<0.05$ shows the inhibitory effect of CSE deficiency, compared to the respective wild-type group 
The early stimulus with lower dose of LPS initiates a complex response of "cell reprograming", a process that involve, among many factors, epigenetic regulatory processes, including histone acetylation. Prior literature shows a promoter-specific NF- $\mathrm{BB}$ recruitment and histone acetylation in the context of multiple LPS-mediated pro-inflammatory and anti-microbial genes [13]. Another body of prior work suggests that LPS tolerance produces an epigenetic regulation that is locus-specific through the delimitation of the acetylation [11].

Our results confirmed that induction of LPS tolerance decreases the production of the pro-inflammatory cytokines TNF- $\alpha$ and IL- 6 in vitro [8, 10, 27]. Our data also confirm that tolerance induction reduces cytokine production in an in vivo model of sepsis, especially in the longer-term protocol employed. We have also demonstrated that LPS tolerance is associated with marked changes in histone acetylation, although in a rather complex pattern, which does not always or directly mirror the observed changes in cytokine production. In other words, the changes in the acetylation of histones during the development of LPS tolerance (as well as in response to the subsequent high-dose LPS challenge) are dynamic and histone-specific. The most consistent pattern that was observed was that the increases in cytokine production in response LPS tend to be associated with reduced histone acetylation, and tolerance tends to increase/reverse these alterations in histone acetylation, while also suppressing cytokine production. This is also consistent with prior reports indicating that during LPS tolerance, histone acetylation contributes to the silencing of proinflammatory gene transcription [28-32]. Moreover, our group demonstrated an association between the reduction of cytokine release and the decrease on histone $\mathrm{H} 3$ acetylation at the IL- 6 and TNF- $\alpha$ promoters in the cell exposed to $\mathrm{H}_{2} \mathrm{~S}$ or $\mathrm{H}_{2} \mathrm{~S}+\mathrm{LPS}$ [27].

As far as the effect of $\mathrm{H}_{2} \mathrm{~S}$ modulation, in the cellbased model, the most consistent and most pronounced finding was that the $\mathrm{H}_{2} \mathrm{~S}$ donor markedly reduced proinflammatory cytokine production, and these effects tended to coincide with marked increases in histone acetylation. These findings continue to be consistent with the patterns seem in our in vitro experimental system, whereby - generally - higher histone acetylation corresponds to lower cytokine production, while lower histone acetylation corresponds to higher cytokine production. However, these patterns are not universally applicable. For instance, in the short-term protocol, the changes in TNF- $\alpha$ production do not correspond with the changes in IL- 6 production, even though, obviously, the histone acetylation patterns (at least, on the macroscale of total $\mathrm{H} 3$ and $\mathrm{H} 4$ acetylation) are the comparable. Moreover, the inhibitory effect of the CBS/CSE inhibitor AOAA on histone acetylation (although it does mirror the stimulatory effect of $\mathrm{H}_{2} \mathrm{~S}$ donor on histone acetylation) did not manifest in any detectable change in LPSinduced cytokine production. Clearly, histone acetylation is only one of many pathways induced by LPS and/or affected by $\mathrm{H}_{2} \mathrm{~S}$ biosynthesis modulation, and the net results (such as cytokine production and the development of tolerance) are the result of a whole host of interacting factors, only some of which have been investigated here.

When designing the current set of experiments, our working hypothesis was that $\mathrm{H}_{2} \mathrm{~S}$ production may be a contributing factor in the development of LPS tolerance. However, the results did not support this hypothesis; the phenomenon of LPS tolerance has developed regardless whether $\mathrm{H}_{2} \mathrm{~S}$ production was attenuated (by pretreating the cells with AOAA), or when $\mathrm{H}_{2} \mathrm{~S}$ levels were enhanced (by pretreating the cells with the $\mathrm{H}_{2} \mathrm{~S}$ donor $\mathrm{NaHS}$ ). The presence of the $\mathrm{H}_{2} \mathrm{~S}$ donor appeared to potentiate the effect of tolerance (resulting in very low cytokine levels in the "TD" group in the longer-term experimental protocols), perhaps indicative that the antiinflammatory pathways that tolerance induces and the anti-inflammatory pathways that $\mathrm{H}_{2} \mathrm{~S}$ induces are additive or synergistic.

However, the in vivo studies of LPS tolerance are not consistent with the conclusions made in the in vitro model: based on the effects of $\mathrm{H}_{2} \mathrm{~S}$ in the in vitro model (where $\mathrm{H}_{2} \mathrm{~S}$ suppresses cytokine production and enhances the anti-inflammatory effect of tolerance), we expected that $\mathrm{CSE}^{-/-}$mice (that have reduced $\mathrm{H}_{2} \mathrm{~S}$ levels) would respond with higher cytokine production or a lesser degree of tolerization; however, the data showed that tolerance developed in $\mathrm{CSE}^{-/-}$mice the same way as in wild-type mice, and, in fact, the amount of cytokines produced in response to high-dose LPS was lower than in wild-type mice.

The current paper has several limitations. For instance, using $\mathrm{CSE}^{-/-}$mice, one can only probe one source of $\mathrm{H}_{2} \mathrm{~S}$ (the one produced by CSE). $\mathrm{CSE}^{-1-}$ mice have lower levels of circulating $\mathrm{H}_{2} \mathrm{~S}$, but, nevertheless, circulating $\mathrm{H}_{2} \mathrm{~S}$ levels are still detectable [33]. Other components of the circulating $\mathrm{H}_{2} \mathrm{~S}$ levels (i.e. $\mathrm{H}_{2} \mathrm{~S}$ produced by cystathionine- $\beta$ synthase [CBS] or 3-mercaptopyruvate sulfurtransferase [3-MST] remain to be investigated in future studies). Another weakness of the current study is that we have only utilized one type of $\mathrm{H}_{2} \mathrm{~S}$ source, the salt NaHS. This compound generates high levels of $\mathrm{H}_{2} \mathrm{~S}$ in the tissue culture medium, which, then decreases over time due to a combination of cellular metabolism and physical processes (outgassing from the culture medium) [34, 35]. Follow-up studies may use $\mathrm{H}_{2} \mathrm{~S}$ donors with longer half-life (e.g. the compound GYY4137) $[35,36]$ or with $\mathrm{H}_{2} \mathrm{~S}$ donors that are targeting $\mathrm{H}_{2} \mathrm{~S}$ to various cellular compartments (e.g. the mitochondrially targeted $\mathrm{H}_{2} \mathrm{~S}$ donor AP39) [37]. 


\section{Conclusions}

Taken together, the current findings are consistent with several lines of independent observations [8-13, 18, 28$32,38,39]$ showing or suggesting that histone acetylation is modulated during LPS tolerance development, and suggest that histone acetylation may, at least in part, contribute to LPS tolerance. The findings also confirm prior observations [27, 40-44] showing that $\mathrm{H}_{2} \mathrm{~S}$ donors can suppress LPS-induced cytokine production in vitro. In contrast, in vivo, LPS-induced $\mathrm{H}_{2} \mathrm{~S}$ production is lower in the $\mathrm{CSE}^{-/-}$mice (which exhibit lower circulating levels of $\mathrm{H}_{2} \mathrm{~S}$ ) [33], suggesting that in this model - as opposed to the results of our in vitro experiments where inhibition of endogenous $\mathrm{H}_{2} \mathrm{~S}$ production did not affect cytokine production - endogenously produced $\mathrm{H}_{2} \mathrm{~S}$ enhances systemic cytokine production. Finally, the presence or absence of $\mathrm{H}_{2} \mathrm{~S}$ does not appear to play a major role in the development of LPS tolerance in the in vitro and in vivo models used in the current study.

\section{Abbreviations}

AOAA: aminooxyacetic acid; BCA: bicinchoninic acid; CBS: cystathionine- $\beta$ synthase; CSE: cystathionine- $\gamma$-lyase; ELISA: enzyme linked immunosorbent assay; ERK: extracellular-signal-regulated kinases; FBS: fetal bovine serum; $\mathrm{H}_{2} \mathrm{~S}$ : hydrogen sulfide; IL-6: interleukin 6; LPS: lipopolysaccharide; MAP kinase: mitogen activated protein kinases; NaHS: sodium hydrosulfide; $\mathrm{O}_{2}$ : oxygen; PDF: polyvinylidene fluoride; PMA: phorbol myristate acetate; RIPA: radioimmunoprecipitation assay; RNS: reactive nitrogen species; ROS: reactive oxygen species; SDS: sodium dodecyl sulfate; TBST: Tris-buffered saline and Tween 20; THP1: Tamm Horsfall Protein 1; TNFa: Tumor Necrosis Factor a.

\section{Competing interests}

The authors declare that they have no competing interests.

\section{Authors' contributions}

Ester C.S. Rios designed and performed experiments, analyzed and interpreted data, prepared figures and wrote part of the manuscript. Francisco G. Soriano designed experiments and analyzed data. Gabor Olah designed experiments. Domokos Gerö performed experiments. Bartosz Szczesny analyzed and interpreted data and wrote part of the paper. Csaba Szabo designed experiments, analyzed and interpreted data and wrote parts of the paper. All authors read and approved the final manuscript.

\section{Acknowledgements}

This work was supported by a grant from the National Institutes of Health (R01 GM107846) to C.S.

\section{Author details}

${ }^{1}$ Department of Emergency Medicine, Universidade de São Paulo Medical School, São Paulo, Brazil. 'Department of Anesthesiology, University of Texas Medical Branch, 601 Harborside Drive, Building 21, Room 4.202D, Galveston, TX 77555-1102, USA

Received: 4 August 2015 Accepted: 28 March 2016

Published online: 01 April 2016

\section{References}

1. Friedman G, Silva E, Vincent JL. Has the mortality of septic shock changed with time. Crit Care Med. 1998;26:2078-86.

2. Angus DC, Linde-Zwirble WT, Lidecker J, Clermont G, Carcillo J, Pinsky MR. Epidemiology of severe sepsis in the United States: analysis of incidence, outcome, and associated costs of care. Crit Care Med. 2001;29:1303-10.

3. Vincent JL, Van der Linden P. Septic shock: particular type of acute circulatory failure. Crit Care Med. 1990;18:S70-4.
4. Woltmann A, Hamann L, Ulmer AJ, Gerdes J, Bruch HP, Rietschel ET. Molecular mechanisms of sepsis. Langenbecks Arch Surg. 1998;383:2-10.

5. McCuskey RS, Urbaschek R, Urbaschek B. The microcirculation during endotoxemia. Cardiovasc Res. 1996:32:752-63.

6. Hinshaw LB. Sepsis/septic shock: participation of the microcirculation: an abbreviated review. Crit Care Med. 1996;24:1072-8.

7. Friedman G, Soriano FG, Rios EC. Sepsis volume reposition with hypertonic saline solution. Rev Bras Ter Intensiva. 2008:20:267-77.

8. El Gazzar M, Yoza BK, Hu JYQ, Cousart SL, McCall CE. Epigenetic silencing of TNF during endotoxin tolerance. J Biol Chem. 2007;282:26857-64.

9. McCall CE, Yoza BK. Gene silencing in severe systemic inflammation. Am J Respir Crit Care Med. 2007;175:763-7.

10. Beutler B, Rietschel ET. Innate immune sensing and its roots: the story of endotoxins. Nat Rev Immunol. 2003;3:169-76.

11. Foster SL, Hargreaves DC, Medzhitov R. Gene-specific control of inflammation by TLR-induced chromatin modifications. Nature. 2007:447:972-8.

12. Natoli G. Tuning up inflammation: how DNA sequence and chromatin organization. FEBS Lett. 2006;580:2843-9.

13. Chan C, Li L, McCall CE, Yoza BK. Endotoxin tolerance disrupts chromatin remodeling and NF-KB transactivation at the IL-1 promoter. J Immunol. 2005;175:461-8.

14. West MA, Heagy W. Endotoxin tolerance: A review. Crit Care Med. 2002:30:564-73

15. Melo ES, Barbeiro HV, Ariga S, Goloubkova T, Curi R, Velasco IT, Vasconcelos $\mathrm{D}$, Soriano FG. Immune cells and oxidative stress in the endotoxin tolerance mouse model. Braz J Med Biol Res. 2010;43:57-67.

16. Hirohashi N, Morrison DC. Low-dose lipopolysaccharide (LPS) pretreatment of mouse macrophages modulates LPS-dependent interleukin-6 production in vitro. Infect Immun. 1996;64:1011-5.

17. Pena OM, Pistolic J, Raj D, Fjell CD, Hancock RE. Endotoxin tolerance represents a distinctive state of alternative polarization (M2) in human mononuclear cells. J Immunol. 2011:186:7243-54.

18. Fernandes ML, Mendes ME, Brunialti MK, Salomão R. Human monocytes tolerant to LPS retain the ability to phagocytose bacteria and generate reactive oxygen species. Braz J Med Biol Res. 2010;43:860-8.

19. Szabo C. Hydrogen sulphide and its therapeutic potential. Nat Rev Drug Discov. 2007;6:917-35.

20. Yang $G$, Wu L, Wang R. Pro-apoptotic effect of endogenous $\mathrm{H}_{2} \mathrm{~S}$ on human aorta smooth muscle cells. FASEB J. 2006;20:553-5.

21. Yang G, Cao K, Wu L, Wang R. Cystathionine $y$-lyase overexpression inhibits cell proliferation via a $\mathrm{H}_{2} \mathrm{~S}$-dependent modulation of ERK1/2 phosphorylation and p21Cip/WAK-1. J Biol Chem. 2004;279:49199-205.

22. Wang R. Physiological implications of hydrogen sulfide: a whiff exploration that blossomed. Physiol Rev. 2012;92:791-896.

23. Kimura $Y$, Kimura $H$. Hydrogen sulfide protects neurons from oxidative stress. FASEB J. 2004;18:1165-7.

24. Truong DH, Eghbal MA, Hindmarsh W, Roth SH, O'Brien PJ. Molecular mechanisms of hydrogen sulfide toxicity. Drug Metab Rev. 2006;38:733-44.

25. Szabo C. Gasotransmitters in cancer: from pathophysiology to experimental therapy. Nat Rev Drug Discov. 2016;15:185-203.

26. Asimakopoulou A, Panopoulos P, Chasapis CT, Coletta C, Zhou Z, Cirino G Giannis A, Szabo C, Spyroulias GA, Papapetropoulos A. Selectivity of commonly used pharmacological inhibitors for cystathionine $\beta$ synthase (CBS) and cystathionine $\gamma$ lyase (CSE). Br J Pharmacol. 2013;169:922-32.

27. Rios EC, Szczesny B, Soriano FG, Olah G, Szabo C. Hydrogen sulfide attenuates cytokine production through the modulation of chromatin remodeling. Int J Mol Med. 2015;35:1741-6.

28. El Gazzar M, Yoza BK, Chen X, Garcia BA, Young NL, McCall CE. Chromatinspecific remodeling by HMGB1 and linker histone $\mathrm{H} 1$ silences proinflammatory genes during endotoxin tolerance. Mol Cell Biol. 2009;29:1959-71.

29. Liu TF, Yoza BK, El Gazzar M, Vachharajani VT, McCall CE. NAD+-dependent SIRT1 deacetylase participates in epigenetic reprogramming during endotoxin tolerance. J Biol Chem. 2011;286:9856-64.

30. Beurel E. HDAC6 regulates LPS-tolerance in astrocytes. PLoS One. 2011;6:e25804.

31. Seeley JJ, Ghosh S. Tolerization of inflammatory gene expression. Cold Spring Harb Symp Quant Biol. 2013;78:69-79.

32. Chen HP, Zhao YT, Zhao TC. Histone deacetylases and mechanisms of regulation of gene expression. Crit Rev Oncog. 2015;20:35-47.

33. Yang G, Wu L, Jiang B, Yang W, Qi J, Cao K, Meng Q, Mustafa AK, Mu W, Zhang S, Snyder SH, Wang R. $\mathrm{H}_{2} \mathrm{~S}$ as a physiologic vasorelaxant: hypertension in mice with deletion of cystathionine gamma-lyase. Science. 2008;322:587-90. 
34. Suzuki K, Olah G, Modis K, Coletta C, Kulp G, Gerö D, Szoleczky P, Chang T, Zhou Z, Wu L, Wang R, Papapetropoulos A, Szabo C. Hydrogen sulfide replacement therapy protects the vascular endothelium in hyperglycemia by preserving mitochondrial function. Proc Natl Acad Sci U S A. 2011;108:13829-34.

35. Papapetropoulos A, Whiteman M, Cirino G. Pharmacological tools for hydrogen sulphide research: a brief, introductory guide for beginners. Br J Pharmacol. 2015;172:1633-7.

36. Li L, Whiteman M, Guan YY, Neo KL, Cheng Y, Lee SW, Zhao Y, Baskar R, Tan $\mathrm{CH}$, Moore PK. Characterization of a novel, water-soluble hydrogen sulfidereleasing molecule (GYY4137): new insights into the biology of hydrogen sulfide. Circulation. 2008;117:2351-60.

37. Szczesny B, Módis K, Yanagi K, Coletta C, Le Trionnaire S, Perry A, Wood ME, Whiteman M, Szabo C. AP39, a novel mitochondria-targeted hydrogen sulfide donor, stimulates cellular bioenergetics, exerts cytoprotective effects and protects against the loss of mitochondrial DNA integrity in oxidatively stressed endothelial cells in vitro. Nitric Oxide. 2014;41:120-30.

38. Schaafsma W, Zhang X, van Zomeren KC, Jacobs S, Georgieva PB, Wolf SA Kettenmann H, Janova H, Saiepour N, Hanisch UK, Meerlo P, van den Elsen PJ, Brouwer N, Boddeke HW, Eggen BJ. Long-lasting pro-inflammatory suppression of microglia by LPS-preconditioning is mediated by RelBdependent epigenetic silencing. Brain Behav Immun. 2015:48:205-21.

39. Neagos J, Standiford TJ, Newstead MW, Zeng X, Huang SK, Ballinger MN Epigenetic regulation of tolerance to TLR ligands in alveolar epithelial cells. Am J Respir Cell Mol Biol. 2015;53:872-81.

40. Fox B, Schantz JT, Haigh R, Wood ME, Moore PK, Viner N, Spencer JP, Winyard $P G$, Whiteman M. Inducible hydrogen sulfide synthesis in chondrocytes and mesenchymal progenitor cells: is $\mathrm{H}_{2} \mathrm{~S}$ a novel cytoprotective mediator in the inflamed joint? J Cell Mol Med. 2012;16:896-910.

41. Aslami H, Beurskens CJ, de Beer FM, Kuipers MT, Roelofs JJ, Hegeman MA Van der Sluijs KF, Schultz MJ, Juffermans NP. A short course of infusion of a hydrogen sulfide-donor attenuates endotoxemia induced organ injury via stimulation of anti-inflammatory pathways, with no additional protection from prolonged infusion. Cytokine. 2013;61:614-21.

42. Coletta C, Szabo C. Potential role of hydrogen sulfide in the pathogenesis of vascular dysfunction in septic shock. Curr Vasc Pharmacol. 2013;11:208-21.

43. Ferlito M, Wang Q, Fulton WB, Colombani PM, Marchionni L, Fox-Talbot K, Paolocci N, Steenbergen C. Hydrogen sulfide increases survival during sepsis: protective effect of CHOP inhibition. J Immunol. 2014;192:1806-14.

44. Xin H, Wang M, Tang W, Shen Z, Miao L, Wu W, Li C, Wang X, Xin X, Zhu Y. Hydrogen sulfide attenuates inflammatory hepcidin by reducing IL-6 secretion and promoting SIRT1-mediated STAT3 deacetylation. Antioxid Redox Signal. 2016;24:70-83.

\section{Submit your next manuscript to BioMed Central and we will help you at every step:}

- We accept pre-submission inquiries

- Our selector tool helps you to find the most relevant journal

- We provide round the clock customer support

- Convenient online submission

- Thorough peer review

- Inclusion in PubMed and all major indexing services

- Maximum visibility for your research

Submit your manuscript at www.biomedcentral.com/submit

) Biomed Central 